Charles Cruise MD FRCPC, John MacKinnon MBChB FFARCS, Judith Tough MD FRCPC, Patricia Houston MD FRCPC

\title{
Comparison of meperi- dine and pancuronium for the treatment of shivering after cardiac surgery
}

\begin{abstract}
Shivering after cardiac surgery can produce adverse haemodynamic and metabolic sequelae. In this study, the metabolic effects of shivering and the efficacy of treatment with meperidine or pancuronium were studied, using a metabolic cart, in 61 patients who had undergone cardiac surgery. The patients received premedication with morphine, perphenazine and diazepam or lorazapam, and were anaesthetised with fentanyl or sufentanil and diazepam. Muscle relaxation was achieved with pancuronium. Patients were monitored with a radial arterial line, pulmonary artery catheter and oesophageal and urinary bladder temperature probes. Rewarming to an oesophageal temperature of $38^{\circ} \mathrm{C}$ was achieved before the termination of $C P B$ and was maintained for a minimum of 15 min reperfusion time. Every 15 min after surgery, the patients" temperature at three sites (pulmonary artery, oesophagus, bladder) and shivering scores were monitored. Hourly measurements were made of haemodynamic variables (MAP, PAOP, CVP, SVR, PVR, $C l)$, carbon dioxide production, oxygen consumption and respi-
\end{abstract}

\section{Key words}

ANALGESICS: meperidine;

CARBON DIOXIDE: production;

HYPOTHERMIA: shivering;

NEUROMUSCULAR RELAXANTS: pancuronium;

OXYGEN: consumption;

SURGERY: cardiovascular;

TEMPERATURE: body.

From the Departments of Anaesthesia and Cardiovascular Surgery, The Toronto Hospital, Toronto Western Division, 399 Bathurst Street, Toronto, Ontario, Canada M5T 2S8.

Address correspondence to: Dr. Charles Cruise, The Toronto Hospital, Toronto Western Division, Department of Anaesthesia, 399 Bathurst Street, Toronto, Ontario, Canada MST 2 S8.

Data presented in part at the 44th Postgraduate Assembly in Anesthesiology of the New York State Society of Anesthesiologists, New York, NY, December 10, 1990.

Accepted for publication 14th March, 1992. ratory quotient. If the patient shivered, the measurements were recorded prior to drug treatment and repeated $30 \mathrm{~min}$ later following randomization to either: meperidine $0.25 \mathrm{mg} \cdot \mathrm{kg}^{-1}$ (Group 1), meperidine $0.5 \mathrm{mg} \cdot \mathrm{kg}^{-1}$ (Group 2) or pancuronium $0.06 \mathrm{mg} \cdot \mathrm{kg}^{-1}$ intravenously (Group 3). Thirty-two patients shivered and mean $\dot{V} \mathrm{O}_{2}$ and $\dot{\mathrm{V}} \mathrm{CO}_{2}$ values were greater in the shivering group than in the nonshivering patients $\left(\dot{V} \mathrm{O}_{2} 334.8\right.$ \pm 17.6 vs. $240.5 \pm 8.8 \mathrm{ml} \cdot \mathrm{min}^{-1} ; \dot{V} \mathrm{CO}_{2} 238.8 \pm 17.2 \mathrm{vs}$ $\left.199.2 \pm 8.4 \mathrm{ml} \cdot \mathrm{min}^{-1}, P=0.0001\right)$. Thirty minutes following treatment the mean $\dot{V} \mathrm{O}_{2}$ in Group 3 was less $(215.9 \pm 24.3$ $\left.\mathrm{ml} \cdot \mathrm{min}^{-1}\right)$ than in Groups $I\left(295.9 \pm 22.0 \mathrm{ml} \cdot \mathrm{min}^{-1}\right)$ and 2 $\left(322.7 \pm 21.0 \mathrm{ml} \cdot \mathrm{min}^{-1}\right)(P<0.01)$. It is concluded that drug treatment with meperidine is not as effective as pancuronium in alleviating the metabolic effects of shivering in these patients.

Les frissons après une chirurgie cardiaque peuvent produire des effets métaboliques et hémodynamiques indésirables. Les effets métaboliques des frissons et l'efficacité du traitement avec mépéridine et pancuronium ont été étudiés à l'aide d'un appareillage métabolique chez 61 patients ayant subi une chirurgie cardiaque. Les patients étaient prémédiqués avec morphine, perphénazine et diazepam ou lorazepam et étaient anesthésiés à l'aide de fentanyl ou sufentanil, diazepam, pancuronium et oxygène. Les patients étaient monitorisés à l'aide d'une canule artérielle radiale, un cathéter dans l'artère pulmonaire et de sondes de température oesophagienne et vésicale. On procédait à un réchauffement jusqu'à des températures oésophagiennes de $38^{\circ} \mathrm{C}$ avant l'arrêt de la circulation extra-corporelle (CEC) et ce réchauffement était maintenu pour un temps de perfusion minimum de 15 minutes. Dans la période post-opératoire, on notait la température du patient à trois sites (artère pulmonaire, oesophage, vessie) à toutes les 15 minutes et le pointage de frissonnement. On prenait des mesures horaires des variables hémodynamiques (MAP, PAOP, CVP, SVR, PVR, CI), de la production de dioxide de carbone, de la consommation d'oxygène et du quotient respiratoire. Si le patient frissonnait, des mesures étaient prises avant le traitement médical et répétées trente minutes plus tard suite au traitement randomisé soit avec 
mépéridine $0,25 \mathrm{mg} \cdot \mathrm{kg}^{-1}$ (groupe l), mépéridine $0,5 \mathrm{mg} \cdot \mathrm{kg}^{-1}$ (groupe 2) ou pancuronium $0,06 \mathrm{mg} \cdot \mathrm{kg}^{-I}$ iv (groupe 3). Trente-deux patients ont frissonné et les valeurs moyennes de $\dot{V}_{2}$ et de $\dot{V} \mathrm{CO}_{2}$ étaient plus élevées chez les patients ayant frissonné que chez les patients n'ayant pas frissonné (VO⿰冫一 $334,8 \pm 17,6$ comparé à $240,5 \pm 8,8 \mathrm{ml} \cdot \mathrm{min}^{-1} ; \dot{V} \mathrm{CO}_{2} 238,8$ $\pm 17,2$ comparé à $\left.199,2 \pm 8,4 \mathrm{ml} \cdot \mathrm{min}^{-1}, P=0,001\right)$. Trente minutes après le traitement, la $\dot{V} \mathrm{O}_{2}$ moyenne dans le groupe 3 était moindre $\left(215,9 \pm 24,3 \mathrm{ml} \cdot \mathrm{min}^{-1}\right)$ que dans les groupes $l\left(295,9 \pm 22,0 \mathrm{ml} \cdot \mathrm{min}^{-1}\right)$ et $2\left(332,7 \pm 21,0 \mathrm{ml} \cdot \mathrm{min}^{-1}\right)(P<$ $0,01)$. L'administration de mépéridine pour le traitement médical du frisson chez ces patients n'est pas aussi efficace que l'utilisation du pancuronium pour atténuer les effets métaboliques.

Shivering often occurs in the early recovery of patients following cardiac surgery with cardiopulmonary bypass. This shivering can be deleterious in that it has frequently been associated with adverse metabolic and haemodynamic sequelae, such as increases in heart rate, cardiac output, oxygen consumption $\left(\mathrm{VO}_{2}\right)$ and carbon dioxide production $\left(\mathrm{VCO}_{2}\right)^{\prime}$ and decreases in mixed venous oxygen saturation. ${ }^{2}$

The metabolic effects of shivering can be assessed using a commercially available device (a metabolic cart) which continuously analyses expired and inspired gases, rapidly detects changes in these variables over time, and can be used to calculate $\mathrm{VO}_{2}$ and $\dot{\mathrm{VCO}}_{2}{ }^{3}$

Although meperidine and pancuronium ${ }^{2}$ have been shown to be effective in the treatment of shivering in postoperative patients, we are unaware of any study documenting the metabolic effects of shivering or its treatment using the metabolic cart in post-cardiac surgical patients.

This study was undertaken to compare the effectiveness of meperidine and pancuronium in the suppression of postoperative shivering, and to document the effects of shivering and its treatment using hemodynamic monitoring and a metabolic cart.

\section{Methods}

After obtaining institutional approval and written informed consent, 61 patients scheduled for elective coronary artery bypass surgery were enrolled in the study. Patients were maintained on their usual medications until the morning of surgery, and received remedication with morphine 10 to $15 \mathrm{mg}$ and perphenazine (a phenothiazine tranquilizer) 5.0 to $7.5 \mathrm{mg} \mathrm{im}$, and diazepam 10 to $15 \mathrm{mg}$ or lorazepam 2 to $4 \mathrm{mg}$ po. Monitoring included the use of radial arterial and pulmonary artery thermodilution catheters (model 93A-131H-7F, American Edwards Laboratories), oesophageal stethoscope temperature probe and a urinary bladder temperature probe
TABLE I Shivering score (after Holtzclaw ${ }^{7}$ )

0 No shivering

1 Palpable mandible vibration or ECG artifact

2 Visible fasciculations of head or neck

3 Visible fasciculations of pectoral muscles or trunk

4 Generalized shivering of entire body

(American Pharmaseal Company, American Hospital Supply Corporation, Valencia, CA).

Patients were anaesthetised using fentanyl (50 to 100 $\mu \mathrm{g} \cdot \mathrm{kg}^{-1}$ ) or sufentanil ( 15 to $30 \mu \mathrm{g} \cdot \mathrm{kg}^{-1}$ ) and diazepam $\left(0.2 \mathrm{mg} \cdot \mathrm{kg}^{-1}\right)$. Muscle relaxation was achieved with pancuronium $\left(0.2 \mathrm{mg} \cdot \mathrm{kg}^{-1}\right)$. Cardiopulmonary bypass (CPB) was instituted using a membrane oxygenator with intermittent cold blood cardioplegia. Following revascularization, rewarming to an oesophageal temperature of $38^{\circ} \mathrm{C}$ occurred before termination of $\mathrm{CPB}$ and was maintained for at least $15 \mathrm{~min}$ of reperfusion time.

After surgery, patients were transferred to the Cardiovascular Intensive Care Unit (CVICU) where they underwent mechanical pulmonary ventilation with warmed and humidified inspired gases. A warming blanket was applied to all patients until the pulmonary artery temperature reached $36^{\circ} \mathrm{C}$.

Haemodynamic variables including heart rate (HR), systolic blood pressure (SBP), diastolic blood pressure (DBP), mean arterial blood pressure (MAP), pulmonary artery pressure (PAP), pulmonary capillary wedge pressure (PCWP), central venous pressure (CVP), cardiac output $(\mathrm{CO})$, cardiac index $(\mathrm{Cl})$ and systemic and pulmonary vascular resistances (SVR, PVR) were measured hourly.

Carbon dioxide production $\left(\mathrm{VCO}_{2}\right)$, oxygen consumption $\left(\mathrm{VO}_{2}\right)$ and respiratory quotient (RQ) were obtained using a Deltatrac metabolic cart (SensorMedics Corporation, Anaheim, CA). The use of this cart has been validated in laboratory ${ }^{4}$ and clinical environments ${ }^{5}$ up to an $\mathrm{FIO}_{2}$ of $0.8,{ }^{6}$ with a high degree of accuracy, and good correlation with other methods of measurement. It was calibrated before use with a calibration gas comprising $96 \%$ oxygen and $4 \%$ carbon dioxide. The inspired oxygen concentration was stable and $\mathrm{RQ}$ was between 0.7 and 1.0 throughout the measurement periods. Each measurement of $\dot{\mathrm{VO}}_{2}, \dot{\mathrm{V}} \mathrm{CO}_{2}$ and $\mathrm{RQ}$ comprised a mean of ten readings at one-minute intervals after stabilization. Temperatures at three sites (pulmonary artery, oesophagus, urinary bladder) were recorded every $15 \mathrm{~min}$.

A shivering score was obtained every $15 \mathrm{~min}$ using the method proposed by Holtzclaw ${ }^{7}$ (Table I). If the shivering score reached 3 or 4 , as graded by two independent observers (JCST, JCM), all haemodynamic, respiratory and metabolic measurements were performed. The patient was then randomized to a treatment group, 
TABLE II Patient characteristics*

\begin{tabular}{|c|c|c|}
\hline Variable & Non-shiverers & Shiverers \\
\hline Age $(y r)$ & $59.1 \pm 1.9$ & $61.3 \pm 1.3$ \\
\hline Height $(\mathrm{cm})$ & $168.2 \pm 2.0$ & $171.2 \pm 1.1$ \\
\hline Weight (kg) & $78.2 \pm 2.8$ & $80.6 \pm 2.1$ \\
\hline \multicolumn{3}{|c|}{ Anaesthetic drugs (number of patients) } \\
\hline Fentanyl $\left(\mu \mathrm{g} \cdot \mathrm{kg}^{-1}\right)$ & $85.7 \pm 3.6(27)$ & $85.4 \pm 3.5(27)$ \\
\hline Pancuronium $\left(\mathrm{mg} \cdot \mathrm{kg}^{-1}\right)$ & $0.20 \pm 0.01(28)$ & $0.19 \pm 0.01(33)$ \\
\hline Sufentanil $\left(\mu \mathrm{g} \cdot \mathrm{kg}^{-1}\right)$ & $16.23(1)$ & $23.04 \pm 3.4(6)$ \\
\hline Diazepam $\left(\mathrm{mg} \cdot \mathrm{kg}^{-1}\right)$ & $0.22 \pm 0.02(23)$ & $0.18 \pm 0.01(23)$ \\
\hline Duration of surgery (min) & $241 \pm 7.4$ & $251 \pm 6.6$ \\
\hline Pump time (min) & $81.2 \pm 3.6$ & $86.1 \pm 4.2$ \\
\hline Reperfusion time (min) & $21.8 \pm 1.3$ & $24.8 \pm 1.6$ \\
\hline \multicolumn{3}{|c|}{ Minimum temperature during CPB: } \\
\hline Pulmonary Artery $\left({ }^{\circ} \mathrm{C}\right)$ & $28.5 \pm 0.53$ & $28.0 \pm 0.52$ \\
\hline Oesophagus $\left({ }^{\circ} \mathrm{C}\right)$ & $28.3 \pm 0.47$ & $28.9 \pm 0.48$ \\
\hline Bladder $\left({ }^{\circ} \mathrm{C}\right)$ & $30.2 \pm 0.61$ & $30.5 \pm 0.50$ \\
\hline \multicolumn{3}{|l|}{ Temperature off $\mathrm{CPB}$ : } \\
\hline Pulmonary Artery $\left({ }^{\circ} \mathrm{C}\right)$ & $37.0 \pm 0.15$ & $37.2 \pm 0.16$ \\
\hline Oesophagus $\left({ }^{\circ} \mathrm{C}\right)$ & $37.6 \pm 0.17$ & $37.8 \pm 0.13$ \\
\hline Bladder $\left({ }^{\circ} \mathrm{C}\right)$ & $36.5 \pm 0.25$ & $36.7 \pm 0.2$ \\
\hline \multicolumn{3}{|l|}{ Temperature on arrival in ICU: } \\
\hline Pulmonary aArtery $\left({ }^{\circ} \mathrm{C}\right)$ & $34.7 \pm 0.12$ & $34.8 \pm 0.12$ \\
\hline Oesophagus $\left({ }^{\circ} \mathrm{C}\right)$ & $34.7 \pm 0.12$ & $34.8 \pm 0.12$ \\
\hline Bladder $\left({ }^{\circ} \mathrm{C}\right)$ & $35.0 \pm 0.16$ & $35.3 \pm 0.16$ \\
\hline $\begin{array}{l}\text { Average morphine dose in } \\
\text { ICU }\left(\mathrm{mg} \cdot \mathrm{hr}^{-1}\right)\end{array}$ & $1.9 \pm 0.3$ & $1.8 \pm 0.4$ \\
\hline $\begin{array}{l}\text { Average midazolam dose in } \\
\text { ICU }\left(\mathrm{mg} \cdot \mathrm{hr}^{-1}\right)\end{array}$ & $0.8 \pm 0.2$ & $0.6 \pm 0.1$ \\
\hline
\end{tabular}

*All data (except Sufentanil dose) are presented as mean \pm SEM. There were no significant differences between groups.

the drug treatment was administered and the measurements were repeated after $30 \mathrm{~min}$.

Patients were randomly allocated to one of three drug treatment groups: (1) meperidine $0.25 \mathrm{mg} \cdot \mathrm{kg}^{-1}$, (2) meperidine $0.5 \mathrm{mg} \cdot \mathrm{kg}^{-1}$, or (3) pancuronium 0.06 $\mathrm{mg} \cdot \mathrm{kg}^{-1} \mathrm{iv}$. If, after $30 \mathrm{~min}$, treatment with meperidine failed to abolish shivering (shivering score $>1$ ), the patient received pancuronium $0.06 \mathrm{mg} \cdot \mathrm{kg}^{-1} i v$.

The protocol allowed patients to receive routine treatment for pain relief and sedation with morphine $2-8 \mathrm{mg}$ $i v$ as required and midazolam either by bolus or intravenous infusion of $1-3 \mathrm{mg} \cdot \mathrm{hr}^{-1}$.

Data were analysed using the SAS/PC statistical package $^{8}$ for $t$ tests for between-group comparisons, and repeated measures analysis of variance (RMANOVA) for multiple inter- and intra-group comparisons. A $P$ value $<0.05$ was considered significant.

\section{Results}

The initial group, before randomisation, consisted of 51 men and ten women. Thirty-three of 61 of these patients shivered $(54 \%)$, and this occurred three times more commonly in males $(31 / 51)$ than females $(2 / 10)$.

Analysis of those who shivered is based on 12 patients in Group 1, 12 patients in Group 2, and nine patients in

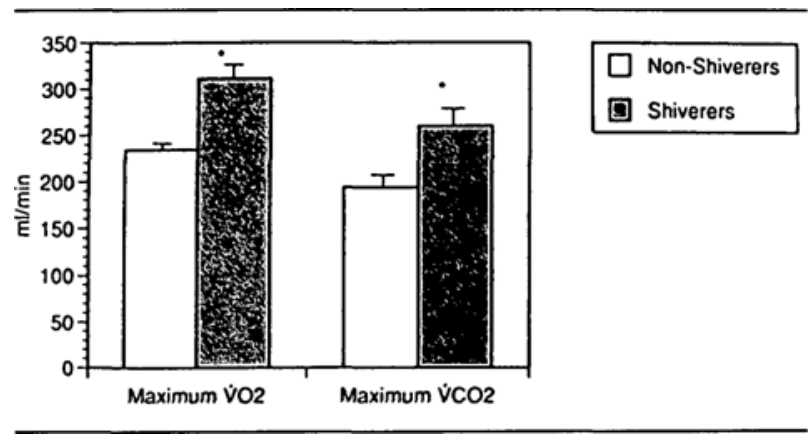

FIGURE 1 Mean \pm SEM of peak oxygen consumption and carbon dioxide production in shivering and non-shivering patients $\left({ }^{*} P=0.0001\right)$.

Group 3; one patient in Group 2 was excluded due to insufficient data. Six of 12 patients in Group $1(50 \%)$ and five of 12 in Group $2(42 \%)$ were treatment failures who required pancuronium to stop their shivering.

Patient and surgical characteristics are summarized in Table II. The groups were matched for age, height, weight and duration of surgery. There were no differences between groups in duration of CPB, lowest temperature reached during $\mathrm{CPB}$, temperature on termination of CPB or reperfusion time. Doses of anaesthetic and sedative drugs received both intra- and postoperatively were similar in the two groups.

The mean time from return to CVICU until shivering occurred was $232 \pm 81 \mathrm{~min}$ and the mean temperature at which patients shivered was $35.9 \pm 0.89^{\circ} \mathrm{C}$.

The maximum $\dot{\mathrm{VO}}_{2}$ values in the patients who shivered were greater than in the non-shiverers (334.8 \pm 17.6 vs $240.5 \pm 8.8 \mathrm{ml} \cdot \mathrm{min}^{-1}, P=0.0001$ ), as were the mean $\dot{\mathrm{VCO}}_{2}$ values $(283.8 \pm 17.2$ vs $199.2 \pm 8.4$ $\mathrm{ml} \cdot \mathrm{min}^{-1}, P=0.0001$ ) (Figure 1).

In the shivering patients, there were no differences between treatment groups in $\mathrm{VO}_{2}$ or $\dot{\mathrm{VCO}}_{2}$ before drug treatment or during shivering. (Figures 2 and 3). Following drug treatment. only patients in Group 3 demonstrated a decrease in $\dot{\mathrm{VO}}_{2}$ at $30 \mathrm{~min}\left(215.5 \pm 24.3 \mathrm{ml} \cdot \mathrm{min}^{-1}\right.$ (Group 3) vs $295.9 \pm 22.0 \mathrm{ml} \cdot \mathrm{min}^{-1}$ (Group 1) and $322.7 \pm 21.0 \mathrm{ml} \cdot \mathrm{min}^{-1}$ (Group 2), $P<0.01$ ) (Figure 2), and the mean $\mathrm{VCO}_{2}$ values in Group 3 tended to be less than in Groups 1 and $2\left(200.3 \pm 24.7 \mathrm{ml} \cdot \mathrm{min}^{-1}\right.$ (Group 3). vs $265.9 \pm 224 \mathrm{ml} \cdot \mathrm{min}^{-1}$ (Group 1) and $280.4 \pm$ $21.4 \mathrm{ml} \cdot \mathrm{min}^{-1}$ (Group 2) (Figure 3).

Haemodynamic variables were similar in the shivering and nonshivering patients at baseline but different for MPAP, CO, CI, and SVR at the time of shivering (see Table III).

\section{Discussion}

Increases in $\dot{\mathrm{VO}}_{2}$ and $\dot{\mathrm{V}} \mathrm{CO}_{2}$ occur in patients who shiver following cardiac surgery. ${ }^{1,2}$ These changes have been associated with increases in heart rate and mean arterial 


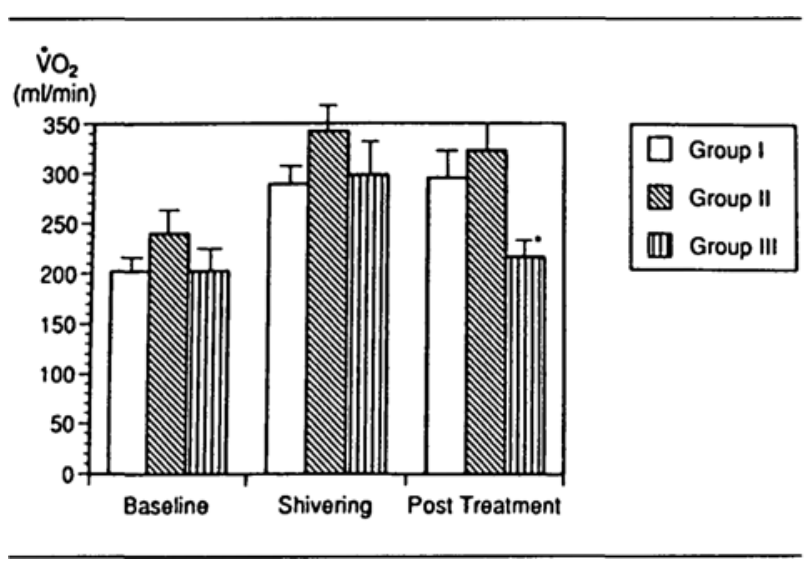

FIGURE 2 Oxygen consumption in shivering patients at baseline, during maximum shivering and following treatment. Values are mean \pm SEM $\left({ }^{*} P<0.01\right)$. See text for group legend

blood pressure ${ }^{9}$ and decreases in mixed venous oxygen saturation $\left(\mathrm{SvO}_{2}\right){ }^{1,2}$ The shivering patient thus may experience increased myocardial work, with deleterious effect on the myocardial supply-demand relationship. ${ }^{10}$

Donati et al. " showed that end tidal carbon dioxide concentrations increase in patients during rewarming after cardiac surgery, probably due to increased $\mathrm{VCO}_{2}$ as a result of increases in metabolic activity. If pulmonary ventilation does not match these increases in $\mathrm{VCO}_{2}$, hypercarbia and acidosis can result. ${ }^{12}$

In the current study, meperidine was administered at two different doses $\left(0.25 \mathrm{mg} \cdot \mathrm{kg}^{-1}\right.$ and $\left.0.5 \mathrm{mg} \cdot \mathrm{kg}^{-1}\right)$ in an attempt to suppress shivering. Our success rate (50\% in Group 1 and $42 \%$ in Group 2) was similar to that previously reported. ${ }^{2}$ More importantly, although our meperidine-treated patients had clinical evidence of shivering suppression, their $\dot{\mathrm{VO}}_{2}$ and $\dot{\mathrm{V}} \mathrm{CO}_{2}$ values remained elevated and did not decline following treatment.

In the present study, only pancuronium was successful at suppressing the clinical and metabolic effects of shivering. Meperidine treatment of shivering, although apparently clinically effective, may delay definitive treatment of the underlying metabolic changes that occur unless facilities for ongoing monitoring of the effectiveness of treatment are available.

Numerous treatments have been proposed for the prevention and amelioration of postoperative shivering in these patients. These include heated humidification of inspired anaesthetic gases, extending rewarming of patients before discontinuation of CPB, and vasodilator therapy to allow more uniform rewarming of patients. ${ }^{13-16}$ None of these has been shown to be effective in minimizing the afterdrop of temperature that occurs after discontinuation of $\mathrm{CPB}$ or in preventing the shivering which may occur.

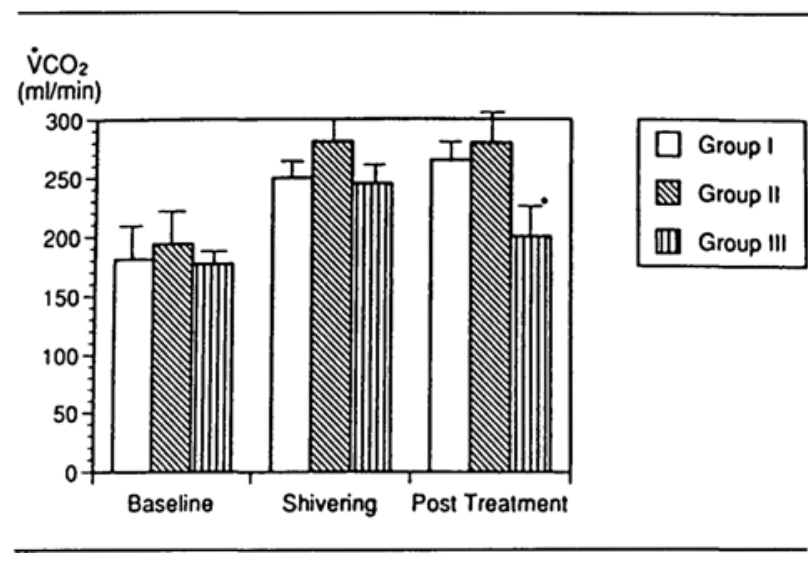

FIGURE 3 Carbon dioxide production in shivering patients at baseline, during maximum shivering and following drug treatment. Values are mean $\pm S E M(* P=0.053)$. See text for group legend.

In cardiac surgical patients, Guffin et al. were able to suppress shivering in 11 of 20 patients using meperidine 25 to $50 \mathrm{mg} i v$, with reductions in shivering and improvements of $\mathrm{SvO}_{2}{ }^{2}$ The remaining nine patients required pancuronium to bring about clinically acceptable values of $\mathrm{SvO}_{2}$. Zwischenberger et al. have shown that patients who received neuromuscular blockers following cardiac surgery displayed smaller increases in $\mathrm{VO}_{2}$ and $\dot{\mathrm{VCO}}_{2}$ and higher systolic blood pressure and mixed venous oxygen saturation than untreated controls. ${ }^{17}$

We used morphine and midazolam for sedation in our patients at small doses that were similar in the shivering and non-shivering groups. Morphine suppresses shivering and its metabolic and haemodynamic sequelae following major surgery, when used in large doses $\left(0.6 \mathrm{mg} \cdot \mathrm{kg}^{-1}\right.$ over seven hours in one study), ${ }^{9}$ but this is far in excess of the doses used in the present study (1.9 \pm 0.3 $\mathrm{mg} \cdot \mathrm{hr}^{-1}$ in shivering patients and $1.8 \pm 0.4 \mathrm{mg} \cdot \mathrm{hr}^{-1}$ in non-shivering patients) (Table II). Others have not found morphine to be as successful as other agents in suppressing shivering in general surgical ${ }^{18}$ or cardiac surgical patients. $^{2}$

The haemodynamic changes found in the present study in the shivering patients (increases in CO, CI, SVR, and MPAP) are in keeping with those shown in previous studies $^{1,2,15}$ and reflect the increases in myocardial work that occur in these patients.

We conclude that shivering following cardiac surgery is most effectively treated with pancuronium, and the effects of treatment are best followed using continous monitoring of metabolic variables using a metabolic cart.

\section{Acknowledgement}

The authors wish to thank Mr. Anthony Ayiomamitis for his expert assistance with statistical analysis of the data. 
TABLE III Haemodynamic data

\begin{tabular}{|c|c|c|c|c|}
\hline Variable & $\begin{array}{l}\text { Measurement } \\
\text { period }\end{array}$ & Shiverers & Non-shiverers & $P$ \\
\hline \multirow{3}{*}{ Heart rate (beats $\cdot \min ^{-1}$ ) } & 1 & $76.9 \pm 2.8$ & $79.6 \pm 2.9$ & NS \\
\hline & 2 & $86.3 \pm 2.1$ & $83.2 \pm 2.9$ & NS \\
\hline & 3 & $91.2 \pm 2.7$ & $86.4 \pm 2.6$ & NS \\
\hline \multirow[t]{3}{*}{ Mean arterial pressure $(\mathrm{mmHg})$} & 1 & $68.0 \pm 2.1$ & $70.6 \pm 1.8$ & NS \\
\hline & 2 & $73.4 \pm 2.2$ & $69.5 \pm 1.8$ & NS \\
\hline & 3 & $67.7 \pm 1.7$ & $69.2 \pm 2.3$ & NS \\
\hline \multirow[t]{3}{*}{ Mean pulmonary artery pressure $(\mathrm{mmHg})$} & 1 & $20.0 \pm 0.6$ & $19.4 \pm 0.8$ & NS \\
\hline & 2 & $24.0 \pm 1.0$ & $20.0 \pm 0.9$ & $<0.05$ \\
\hline & 3 & $20.9 \pm 0.7$ & $20.8 \pm 0.7$ & NS \\
\hline \multirow[t]{3}{*}{ Pulmonary capillary wedge pressure $(\mathrm{mmHg})$} & 1 & $15.7 \pm 0.6$ & $15.4 \pm 0.7$ & NS \\
\hline & 2 & $17.3 \pm 0.9$ & $15.1 \pm 0.7$ & NS \\
\hline & 3 & $15.5 \pm 0.7$ & $15.7 \pm 0.8$ & NS \\
\hline \multirow[t]{3}{*}{ Central venous pressure $(\mathrm{mmHg})$} & 1 & $13.7 \pm 0.5$ & $13.0 \pm 0.7$ & NS \\
\hline & 2 & $15.7 \pm 0.9$ & $14.0 \pm 0.7$ & NS \\
\hline & 3 & $14.6 \pm 0.6$ & $14.5 \pm 0.7$ & NS \\
\hline \multirow[t]{3}{*}{ Cardiac output $\left(L \cdot \min ^{-1}\right)$} & 1 & $6.0 \pm 0.3$ & $5.4 \pm 0.3$ & NS \\
\hline & 2 & $7.1 \pm 0.4$ & $5.8 \pm 0.4$ & $<0.05$ \\
\hline & 3 & $6.8 \pm 0.3$ & $6.1 \pm 0.4$ & NS \\
\hline \multirow[t]{3}{*}{ Systemic vascular resistance $\left(\right.$ dynes $\cdot \mathrm{cm} \cdot \mathrm{sec}^{-5}$ ) } & 1 & $800 \pm 47$ & $894 \pm 49$ & NS \\
\hline & 2 & $703 \pm 45$ & $868 \pm 60$ & $<0.05$ \\
\hline & 3 & $678 \pm 46$ & $770 \pm 49$ & NS \\
\hline \multirow[t]{3}{*}{ Pulmonary vascular resistance (dynes $\cdot \mathrm{sec} \cdot \mathrm{cm}^{-5}$ ) } & 1 & $72.7 \pm 10.0$ & $64.9 \pm 8.1$ & NS \\
\hline & 2 & $84.0 \pm 9.6$ & $73.2 \pm 9.1$ & NS \\
\hline & 3 & $71.3 \pm 8.6$ & $73.5 \pm 9.9$ & NS \\
\hline \multirow{3}{*}{ Cardiac index $\left(\mathrm{L} \cdot \mathrm{min}^{-1} \cdot \mathrm{m}^{-2}\right)$} & 1 & $3.1 \pm 0.2$ & $2.8 \pm 0.1$ & NS \\
\hline & 2 & $3.7 \pm 0.2$ & $3.0 \pm 0.2$ & $<0.05$ \\
\hline & 3 & $3.5 \pm 0.2$ & $3.2 \pm 0.2$ & NS \\
\hline
\end{tabular}

Measurement period 1 = before shivering; 2 = maximum shivering; $3=$ following treatment. Values are mean \pm SEM.

\section{References}

1 Ralley FE, Wynands JE, Ramsay JG, et al. The effects of shivering on oxygen consumption and carbon dioxide production in patients rewarming from hypothermic cardiopulmonary bypass. Can J Anaesth 1988; 35 : 332-7.

2 Guffin A, Girard D, Kaplan J. Shivering following cardiac surgery: hemodynamic changes and reversal. Journal of Cardiothoracic Anesthesia 1987; 1: 24-8.

3 Damask MC, Schwarz $Y$, Weissman C. Energy measurements and requirements of critically ill patients. In: Weissman C (Ed). Critical Care Clinics, vol 3., Philadelphia, PA: W.B. Saunders Company, 1987; 71-96.

4 Makita K, Nunn JF, Royston B. Evaluation of metabolic measuring instruments for use in critically ill patients. Crit Care Med 1990; 18: 638-44.

5 Takala J, Kleinanen $O$, Vaisanen $P$, Kari A. Measurement of gas exchange in intensive care; laboratory and clinical validation of a new device. Crit Care Med 1989; 17: 1041-7.

6 Phang PT, Rich T, Ronco J. A validation and compari- son study of two metabolic monitors. J Parenter Enteral Nutr 1990; 14: 259-61.

7 Holtzclaw BJ. Postoperative shivering after cardiac surgery: a review. Heart \& Lung 1986; 15: 292-300.

8 SAS User's Guide. Statistics. Cary, SAS Institute Inc., 1982.

9 Rodriguez JL, Weissman C, Damask MC, et al. Morphine and postoperative rewarming in critically ill patients. Circulation 1983; 68: 1238-46.

10 Buckberg GD, Archie JP, Fixler DE, Hoffman JIE. Experimental subendocardial ischemia during left ventricular hypertension. Surg Forum 1971; 22: 124-5.

11 Donati F, Maille JG, Blain R, et al. End-tidal carbon dioxide tension and temperature changes after coronary artery bypass surgery. Can Anaesth Soc J 1985; 32 : 272-7.

12 Sladen $R N$. Temperature and ventilation after hypothermic cardiopulmonary bypass. Anesth Analg 1985; 64: 816-21.

13 Ralley $F E$, Ramsay $J G$, Wynands $J E$, et al. Effect of heated humidfied gases on temperature drop after cardiopulmonary bypass. Anesth Analg 1984; 63: 1106-10. 
14 Joachimsson PO, Nystrom SO, Tyden H. Postoperative ventilatory and circulatory effects of extended rewarming during cardiopulmonary bypass. Can J Anaesth 1989; 36: 9-19.

15 Noback CR, Tinker JH. Hypothermia after cardiopulmonary bypass in man: amelioration by nitroprusside-induced vasodilation during rewarming. Anesthesiology 1980; 53: 277-80.

16 Bridges KG, Reichard GA, Macvaugh $H$, et al. Effect of phentolamine in controlling temperature and acidosis associated with cardiopulmonary bypass. Crit Care Med 1985; 13: 72-6.

17 Zwischenberger JB, Kirsh MM, Dechert RE, et al. Suppression of shivering decreases oxygen consumption and improves hemodynamic stability during postoperative rewarming. Ann Thorac Surg 1987; 43: 428-31.

18 Pauca AL, Savage RT, Simpson S, Roy RC. Effect of pethidine, fentanyl and morphine on postoperative shivering in man. Acta Anaesthesiol Scand 1984; 28: 138-43. 